\title{
DERECHO A LA VERDAD Y CÁNONES DE VERACIDAD
}

\author{
Right to the truth and canons of veracity
}

\author{
Ana Galdámez Morales \\ Contratada predoctoral FPU, Departamento de Derecho Constitucional \\ de la Universidad de Sevilla
}

http://dx.doi.org/10.18543/ed-69(2)-2021pp77-110

Recibido: 23.11.2021

Aceptado: 13.12 .2021

\section{Resumen}

Que el hecho narrado se ajuste a la verdad — a la realidad — resulta indiferente; lo esencial de cara a la protección constitucional de la información - además de la relevancia pública - es que se respete el límite de la veracidad. Un concepto que ha quedado obsoleto en el contexto de la comunicación digital y requiere de una reformulación conforme a las circunstancias de nuestro presente. En este sentido, el perfil de quien ejerce el derecho resulta determinante: no es posible aplicar el mismo concepto de veracidad a la redacción de un periodista - profesional de los medios de comunicación, sujeto a un deber de diligencia - que al discurso que un ciudadano publica en sus redes sociales. Ha cambiado el paradigma comunicativo y, con él, deben hacerlo las categorías jurídicas y los parámetros normativos que manejamos. Partiendo de esta premisa, el presente trabajo ha sido elaborado en clave propositiva para sugerir el tránsito desde el concepto clásico de veracidad, hacia un abanico integrado por diversos cánones de veracidad.

\section{Palabras clave}

Verdad; veracidad; posverdad; libertad de información; opinión pública.

\section{Abstract}

It is not important that the fact of the news corresponds to the truth - to realityThe essential thing for the constitutional protection of information - apart from 
public relevance - is the respect of the other limit: veracity. It is an obsolete concept in the context of digital communication, and requires a reformulation according to the circumstances of our present. In this sense, the profile of the person who exercises the right is decisive: it is not possible to apply the same concept of veracity to a journalist - a mass media professional, subject to a duty of diligence - than to the speech that a citizen publishes on their social networks. The communication paradigm has changed and, with it, so must the legal categories we handle. Based on this need for renewal, this paper has been prepared to suggest the transition from the classic concept of veracity, to a range of veracity's canons.

\section{Keywords}

Truth; veracity; post-truth; Freedom of press; public opinion. 


\begin{abstract}
SuMARIO: I. INTRODUCCIÓN. II. OBSOLESCENCIA DE LAS CATEGORÍAS JURÍDICAS EN LA SOCIEDAD DE LA INFORMACIÓN. 1. La comunicación en el contexto digital: elementos determinantes. 2. Nuevas herramientas, nuevos usos; viejos patrones conceptuales. III. DERECHO A RECIBIR INFORMACIÓN VERAZ Y BÚSQUEDA DE LA VERDAD. 1. ¿Tenemos derecho a recibir información veraz? 2. Eficacia del derecho a recibir información veraz en la búsqueda de la verdad. IV. LA VERACIDAD COMO LÍMITE AL EJERCICIO DE LA LIBERTAD DE INFORMACIÓN. 1. Veracidad $y$ diligencia profesional en la jurisprudencia del TC. V. EN CLAVE PROPOSITIVA: DEL CONCEPTO CLÁSICO A LOS CÁNONES DE VERACIDAD. VI. BIBLIOGRAFÍA.
\end{abstract}

\title{
I. INTRODUCCIÓN
}

\author{
"¿Tu verdad? No, la Verdad, \\ $y$ ven conmigo a buscarla. \\ La tuya, guárdatela».
}

Antonio Machado. Proverbios y cantares.

Hace ya varios años que la desinformación, y su efecto sobre la democracia, se erige como una de las principales preocupaciones de los poderes públicos ${ }^{1}$. La proliferación, gracias a las tecnologías digitales (Freelon y Wells, 2020), de fake news capaces de afectar y de desvirtuar el proceso de construcción de la opinión pública (Habermas, 1981: 261-64) y, en definitiva, la legitimidad del sistema representativo ${ }^{2}$ se ha situado en el centro del debate, a pesar de las voces que insisten restarle novedad e importancia. No podemos decir que Internet sea algo nuevo; los bulos y la mentira como instrumento de manipulación, tampoco. Sin embargo, aún a riesgo de resultar poco original, me aventuro a comenzar aludiendo a la irrupción del nuevo contexto tecnológico y digital, que lo cambia todo.

Podemos, por ejemplo, afirmar la existencia de determinados seres mitológicos en el Océano Pacífico. Incluso, redactarlo en forma de noticia,

${ }^{1}$ Desde las elecciones presidenciales americanas de 2016 se viene hablando del fenómeno de la posverdad: del nuevo escenario comunicativo en el que las noticias falsas pueden adulterar el proceso de toma de decisión de los electores generando un clima de desconfianza.

2 Consecuencias de la mentira en la información, sobre las que mucho se ha escrito, a las que recientemente - desde el inicio de la pandemia - se vienen sumado nuevos riesgos: bienes jurídicos colectivos, como la salud pública, la seguridad o el normal funcionamiento de las instituciones, afectados por la propagación de bulos sobre la enfermedad (Barrientos-Báez et al., 2021; Salaverría et al., 2020). 
apoyando el discurso con imágenes retocadas y sólidos —en aparienciaargumentos de autoridad para, finalmente, publicarlo en Facebook o Twitter. Comprobaremos que, sin dejar de ser más que una invención, se trata de un contenido que nace con una capacidad innata: la de viajar a través de la red para llegar mucho más lejos de lo que, hace solo unos años, no hubiéramos podido ni imaginar. El experimento ya se ha realizado con éxito en varios centros escolares (Cantó, 2017), poniendo en circulación un dibujo hecho por los propios alumnos que ven, en pocas horas, cómo pierden el control de un contenido que se hace viral. Y es que se impone un nuevo paradigma comunicativo cuyos efectos resultan determinantes en la medida en que nos obligan a una revisión del marco normativo (Rodríguez-Izquierdo Serrano, 2015: 149-50) y de los conceptos jurídicos que aplicamos ${ }^{3}$, pensados para un modelo comunicativo obsoleto, sin que ello implique la deconstrucción de todos los presupuestos epistemológicos de los derechos de la comunicación (Vázquez Alonso, 2020b: 477).

¿Cómo podemos defendernos de la mentira en la información?, ¿es posible determinar si algo es falso o cierto?, ¿qué clase de organismo debe asumir las competencias en materia de desinformación?, ¿cómo hacemos frente a las noticias falsas que afectan a la salud pública?, ¿y a la negación de una verdad histórica? Aquello que cuenta con un sólido respaldo científico y aval del método, ¿no es acaso una verdad empírica? Se trata de interrogantes a los que no se pretende dar respuesta adecuada en estas páginas, redactadas a partir de una distinción terminológica — sobradamente conocida - que conviene subrayar: verdad no es sinónimo de veracidad; la confusión de ambos conceptos puede llevarnos a un escenario de imposición de la verdad oficial, que nos aleje del sentido que adquiere el derecho a la información en nuestro ordenamiento. Es, precisamente, este segundo concepto, su definición y los criterios establecidos por el Tribunal Constitucional para su identificación, así como el análisis acerca de la necesidad —o no- de su adecuación al nuevo escenario digital, el que justifica la presente investigación.

Sabemos que el límite interno en el ejercicio del derecho a la libertad de información reconocido en el art. 20.1 d) CE, no es la verdad ${ }^{4}$, sino la exigencia de veracidad de los contenidos que se transmiten. Es éste un concepto jurídico que el Tribunal Constitucional ha definido como el «deber de

${ }^{3}$ Conviene, en las actuales circunstancias, superar las propuestas orientadas a ofrecer un tratamiento diferenciado al contenido de la información en razón del medio o canal de transmisión, puesto que no asistimos a la emergencia de un soporte — como pudo ser en su día la radio o la televisión- sino a un nuevo contexto.

${ }^{4}$ El motivo ha sido reiterado por el TC: «de imponerse la verdad como condición para el reconocimiento del derecho la única garantía de seguridad jurídica sería el silencio», en STC 158/2003, FJ 6. 
diligencia del profesional en el proceso de elaboración de la información» (STC 54/2004, FJ 4; STC 61/2004, FJ 4). Un deber cuya observancia no excluye la posibilidad del error, pero - en caso de conflicto con otro derecho fundamental - sí exime de responsabilidad: siempre y cuando el periodista haya sido diligente y haya contrastado suficientemente la información ${ }^{5}$, no como exigencia de fidelidad con los hechos o de certeza absoluta, sino de rigor en el ejercicio de la actividad profesional.

Es cierto que el objeto del ejercicio del derecho sigue siendo el mismo - la esencia de la comunicación se mantiene-, a pesar de la generalización de nuevos medios para la difusión de los diferentes discursos ${ }^{6}$. Sin embargo, en el actual contexto, es innegable que las plataformas y canales de la comunicación digital han propiciado una transformación de los patrones clásicos; una revolución (Teruel Lozano, 2016: 43) en la que se abren paso nuevos actores - también titulares del derecho a la libertad de información y, por tanto, informadores - que narran y transmiten hechos sin otra herramienta que su teléfono móvil. No estamos solo ante la llegada de un nuevo medio de comunicación, con sus peculiaridades propias, sino ante la consolidación de un marco comunicativo definido por rasgos propios, entre ellos, la ampliación del elemento subjetivo de la ecuación: todos podemos informar (De Miguel Bárcena, 2016: 151) — sin que se nos exija el carné profesional-, con un alcance y capacidad de difusión similar a la de cualquier medio convencional. Ciudadanos de a pie, que ejercen su derecho a transmitir información veraz, a quienes no podemos aplicar el límite de la veracidad; al menos, no como lo hemos entendido hasta ahora (Escobar Roca, 2018: 102).

Pero no debemos olvidar que también existe un derecho a recibir información veraz que, aunque no pueda exigirse de forma directa, sí debería poder esgrimirse como principio para la exigencia de responsabilidad (Carrillo, 2013: 13) en la aplicación de ciertas reglas que garanticen la veracidad de los contenidos que se difunden, en función de las circunstancias del caso concreto, a fin de reformular los «presupuestos desde los cuales hemos venido juzgando los límites al ejercicio de estos derechos», (Vázquez Alonso, 2020: 477).

\footnotetext{
${ }^{5}$ Volveremos sobre esta definición y los criterios establecidos por el TC para su identificación.

${ }^{6}$ Frente a quienes defienden que el nuevo contexto digital no justifica un tratamiento jurídico diferenciado de los contenidos - hechos u opiniones que se transmiten a través de Internet-, se sitúan quienes entienden que el nuevo marco tecnológico obliga a una necesaria reformulación de los parámetros normativos que aplicamos a los derechos de la comunicación (Rodríguez-Izquierdo Serrano, 2015: 150), en la medida en que el desarrollo de la informática y sus implicaciones, genera profundas transformaciones en el funcionamiento de nuestro Derecho (Boix Palop, 2020: 225).
} 
En este sentido, partiendo de la delimitación constitucional del concepto clásico de veracidad — separado de la verdad ${ }^{7}$ como criterio absoluto- se aborda, en los aparatados que siguen, una revisión de esta categoría jurídica - que encuentra su fundamento en el derecho a recibir información verazpara adaptarla a las exigencias derivadas del marco comunicativo vigente, pasando del singular al plural, a través de un abanico de cánones de veracidad, aplicables en función de las cualidades del emisor, así como del sector de actividad profesional que se desarrolle.

\section{OBSOLESCENCIA DE LAS CATEGORÍAS JURÍDICAS EN LA SOCIEDAD DE LA INFORMACIÓN}

A menudo, cuando nos conectamos y deslizamos la vista por el muro de la red social ${ }^{8}$, nos encontramos con titulares de origen dudoso; publicaciones que algún conocido ha podido ver y compartir — en la mayoría de los casos, sin preocuparse por conocer su procedencia - como eslabón de una cadena que acumula varios cientos de likes y numerosos comentarios, con amplísima capacidad de alcance. Es una práctica que se ha integrado en la vida cotidiana de millones de personas en todo el mundo y que describe el contexto comunicativo vigente (Boix Palop, 2016), en el que se imponen nuevos patrones de creación y consumo de la información. Es cierto que se ha escrito mucho al respecto; desde la década de los 90 se acumulan las aportaciones doctrinales ${ }^{9}$ sobre los efectos de la que el sociólogo Manuel Castells (2006) describió como una sociedad en red, pero conviene comenzar destacando - sin ánimo de exhaustividad - aquellas características fundamentales; los rasgos definitorios del nuevo marco tecnológico, que resultan determinantes y que repercuten, inevitablemente, en los conceptos jurídicos que manejamos.

\section{La comunicación en el contexto digital: elementos determinantes}

Puede resultar útil establecer una primera clasificación, en función del carácter subjetivo u objetivo de estos rasgos o elementos definitorios. Comenzaremos por el segundo grupo, en el que enmarcamos aquellas características y efectos - objetivos - derivados del propio medio como canal de comunicación.

${ }^{7}$ «La verdad es asunto de cada cual, que a lo sumo se confronta en el debate público (libertad de expresión e información)» (Villaverde Menéndez, 2016: 153).

8 Título original «The Social Network», 2010. Película dirigida por David Fincher sobre el origen de Facebook.

9 Nos limitaremos a mencionar aquí aquellos elementos que inciden de manera directa en el objeto de estudio del presente trabajo. 
Boix Palop destaca el que quizás sea el más relevante de estos elementos: la capacidad de difusión masiva de unos contenidos que «históricamente quedaban en un ámbito, si no privado, sí restringido, propio de las relaciones de familiaridad [...] y a día de hoy tienen un alcance mucho mayor» (Boix Palop, 2016: 4). Los mensajes son potencialmente virales desde que se publican, gracias a la aparición de plataformas ${ }^{10}$ que facilitan el contacto virtual entre personas y el flujo de información. En este sentido, las redes sociales que más interés suscitan son las que permiten no sólo la interacción con otros contactos, sino también la difusión de contenidos de naturaleza discursiva, como sucede en el caso de Twitter y Facebook. Algo distinto es el funcionamiento de redes como WhatsApp o Telegram, que también permiten el intercambio de opiniones e informaciones, aunque de forma individualizada o en grupos reducidos. En estas plataformas es donde se plantean, con mayor frecuencia, problemas relacionados con los límites que se imponen al ejercicio de las libertades de expresión e información, cosa que no sucede en otras redes sociales como, por ejemplo, Instagram o Youtube —orientadas principalmente a la publicación de imagen y vídeo- $-\mathrm{y}$, por tanto, sede de otro tipo de conflictos propios del material audiovisual.

Son las redes sociales del primer tipo ${ }^{11}$ las que operan, sin que puedan llegar a considerarse medios de comunicación convencionales, como «foros» ${ }^{12}$ o canales de comunicación con capacidad para alojar el proceso de construcción de la opinión pública. Su papel como canales del nuevo sistema de comunicación no puede ignorarse, fundamentalmente por el alcance de los mensajes; un alcance que puede medirse como distancia física, - todo llega más lejos- en número de receptores de la información - alcance subjetivo-y en términos de tiempo. El alcance temporal, que también aumenta considerablemente, es el que podemos considerar el segundo elemento determinante: la permanencia.

Los contenidos llegan más lejos y con una pervivencia también mayor. Los mensajes que se propagan quedan almacenados — no se trata de emitir, sino de colgar el contenido- en bases de datos y archivo digital de los

${ }^{10}$ Existe abundante bibliografía sobre el funcionamiento de las redes sociales. Para un estudio más profundo de la perspectiva de las ciencias sociales, Molina (1995) y Santos (2008). Si se prefiere un enfoque general desde el punto de vista histórico y técnico de las redes sociales más conocidas (Facebook, Twitter, MySpace y LinkedIn), véase Casella (2015).

${ }_{11}$ Las asimilables a Twitter y Facebook.

12 La necesidad de determinar la naturaleza de estos foros y subforos, estriba en la determinación de su naturaleza — pública o privada -; algo esencial a la hora de abordar el debate sobre la regulación (Barnett Lidsky, 2011; Feldman, 2018) del discurso que se difunde dentro de ellas, «en un contexto en el que la separación clásica entre foros privados y foros públicos parece difuminarse» (Vázquez Alonso, 2020b: 478). 
servidores de forma permanente, salvo que actuemos en sentido contrario; algo que se torna especialmente peligroso cuando hablamos de contenidos falsos creados fraudulentamente por medio de portales «con apariencia de páginas web, que pretenden engañar a los usuarios de la red y lucrarse de ingresos publicitarios por cada clic» (Pauner Chulvi, 2018: 302). Esto se produce gracias, entre otras cosas, al acceso universal ${ }^{13}$ - que sería el tercer rasgo determinante - y que nos conduce directamente a los elementos subjetivos del nuevo marco digital de la comunicación, que pueden englobarse en uno sola categoría: los actores de la sociedad de la información.

En un contexto de libre acceso en el que los usuarios operan alternando los roles de emisor y receptor, según el caso, e interactuando de forma instantánea con otros sujetos, se desdibuja la línea divisoria entre creadores y destinatarios de los contenidos. Hasta ahora, identificábamos como sujetos principales a los medios de comunicación convencionales, periodistas y profesionales de la información, de un lado, y a los receptores de dicha información, lectores, oyentes o telespectadores, de otro. Un esquema que se complica con la irrupción de múltiples actores (Balkin, 2018). Destacan, entre ellos, las plataformas, redes sociales y canales digitales de transmisión de la información ${ }^{14}$ - desempeñando el papel de la difusión de los contenidos-, así como —en el estadio necesariamente previo de la creación- los ciudadanos que emiten mensajes y actúan como informadores, rompiéndose la barrera entre éstos y los periodistas.

\section{Nuevas herramientas, nuevos usos; viejos patrones conceptuales}

Sirva este breve apunte de los rasgos y características fundamentales, para dibujar un mosaico comunicativo en el que la velocidad y la inmediatez (Suárez Villegas, 2015: 97) cobran el protagonismo cedido por viejas prácticas como la reflexión y el tratamiento sosegado de los temas ${ }^{15}$. Los patrones de consumo también se invierten; lo que era habitual y cotidiano hace unos años, hoy resulta raro. En lugar de acudir, en busca de la información, a comprar un periódico, hoy es la información la que llega hasta nosotros, nos

13 Todo aquel que tenga acceso a las nuevas tecnologías puede operar en la red, desde cualquier lugar del mundo, como emisor o como receptor de la información.

${ }_{14}$ Plataformas, que son empresas tecnológicas y, sin embargo, se les confiere una responsabilidad cada vez mayor como «garantes interpuestos» en la gestión de los contenidos (Rodríguez-Izquierdo Serrano, 2019: 98). En este sentido, Cotino Hueso (2017).

${ }^{15}$ La exigencia de información inmediata, constantemente actualizada, que retransmita casi en directo todo lo que acontece, impone nuevos patrones de producción informativa que casan mal con los deberes de diligencia profesional y contraste de fuentes exigidos por el límite de la veracidad (Suárez Villegas y Cruz Álvarez, 2013: 7 y 8). 
inunda y nos persigue en forma de titulares breves que tan rápido aparecen en la pantalla, como desaparecen seguidos de cerca por el siguiente mensaje. Es el caldo de cultivo perfecto para que las noticias falsas; la mentira en sus diferentes modalidades - información falseada o manipulada, bulos creados con una determinada intención-, viajen a través de la red influyendo inevitablemente en el debate público.

En este contexto, lo esencial de cara a la protección constitucional de la información — además de la relevancia pública - es que se respete el límite de la veracidad. Y, en este sentido, el perfil — renovado- del sujeto que ejerce el derecho resulta determinante: no es posible aplicar el mismo concepto de veracidad a un periodista - profesional de los medios de comunicación, sujeto a un deber de diligencia en el desarrollo de su actividad- que a un ciudadano que publica en sus redes sociales (Vraga y Bode, 2020). Por este motivo, se hace necesario acometer la búsqueda que nos lleve al modo más adecuado de exigir esta responsabilidad, adaptándola al sujeto que ejerce el derecho. En este sentido, sobre la base del derecho a recibir información veraz, interpretado como principio rector, podemos entender justificada la aplicación de ciertas reglas que garanticen con carácter general la veracidad de los contenidos que se publican, atendiendo a las circunstancias del caso concreto. No se pretende dar respuesta a los nuevos retos jurídicos endureciendo los límites previstos en la normativa específica para la comunicación en Internet; tampoco propiciar la imposición de una verdad oficial de dudoso encaje constitucional (Urías Martínez, 2020; Vázquez Alonso, 2020a); el objetivo es modernizar las técnicas tradicionales y de reformular los límites y criterios establecidos para el ejercicio de estos derechos, de modo que se adapten al nuevo contexto.

\section{DERECHO A RECIBIR INFORMACIÓN VERAZ Y BÚSQUEDA DE LA VERDAD}

«Sólo su verdadero nombre hace reales a todos los seres y todas las cosas - dijo ella-. Un nombre falso lo convierte todo en irreal. Eso es lo que hace la mentira».

La Historia Interminable. Michael Ende.

Podemos hablar de verdad y derecho, como conceptos interrelacionados, al menos, en tres planos diferenciados: el de la verdad judicial; la verdad histórica en el contexto de la llamada justicia transicional; y el de la verdad en el terreno comunicativo y de las ideas. En todos ellos se ha planteado la cuestión de si tenemos - y podemos reclamarlo - derecho a conocer la verdad; $\mathrm{y}$, en este sentido, qué es la verdad. 
Huelga decir que no estamos ante un concepto unívoco (Serra Cristóbal, 2021: 207); aquello que consideremos cierto, aquí y ahora, puede no serlo en otras latitudes o puede - pareciendo cierto hoy - demostrarse dentro de unos años que realmente nunca lo fue. Es ampliamente compartida la interpretación de la verdad como entelequia reservada a la esfera personal de cada individuo; o como consenso ${ }^{16}$, sobre la base de la aceptación colectiva de unos mínimos parámetros comunes que hacen posible el entendimiento recíproco, a partir de una serie de normas y valores compartidos. Es la verdad que se describe, en Habermas (1973: 212) como «pretensión de validez de los enunciados de los cuales nos servimos en nuestras afirmaciones» (citado por Belardinelli, 1991: 122), nunca como imposición. El concepto de verdad, por el contrario, equiparado a la «existencia real de las cosas, no es más que una idea ontológicamente razonable» pero, «sin trascendencia jurídica» (Urías Martínez, 2014: 110).

La verdad, más que una realidad, se define como un objetivo, una búsqueda o un camino, siendo éste un concepto mucho más cercano y asimilable a la exigencia de veracidad. Sin embargo, la verdad en el terreno de lo jurídico opera en planos diversos, con un alcance y tratamiento sobre los cuales merece la pena reflexionar.

\section{1. ¿Tenemos derecho a recibir información veraz?}

El Tribunal Europeo de Derechos Humanos ha reconocido la dimensión individual del «derecho a la verdad», en el ámbito procesal, como «obligación positiva de los Estados de realizar la adecuada investigación de las circunstancias de una violación de los derechos del Convenio», a efectos de proporcionar la correspondiente protección a las víctimas (López Guerra, 2018: 11). A pesar de la trascendencia y el interés público que se confiere a la necesaria investigación sobre vulneraciones de derechos, esto no se traduce en el reconocimiento de un derecho de titularidad colectiva en el que se extienda la legitimación - que pertenece a las víctimas directas o indirectas de dichas violaciones - (López Guerra, 2018: 25) para reclamar su cumplimiento. Sin embargo, en la sentencia del caso Magyar Helsinki Bizottsag c. Hungría, en el año 2016, se introduce una interpretación del art. 10 del Convenio - derecho a recibir y suministrar información - orientada al reconocimiento de un derecho de acceso a la información pública ${ }^{17}$ que se encuentre en manos del

${ }^{16}$ En los años 70 Habermas formula la teoría consensual de la verdad, afrontando la tarea de «identificar y reconstruir las condiciones universales de una posible comunicación» (Belardinelli, 1991: 115).

17 Sobre la importancia de la transparencia y el derecho de acceso a la información pública «para el desarrollo de una adecuada cultura de rendición de cuentas de las admi- 
Estado, otorgando un papel determinante a nuevos sujetos legitimados para solicitarla: periodistas, organizaciones no gubernamentales, académicos o investigadores ${ }^{18}$. En este sentido, sí podría hablarse de la existencia de un «derecho a la verdad», entendido como el derecho a tener acceso a dicha verdad - siempre que se trate de obtener información elaborada que ya se encuentre en manos del Estado- «cuyo ejercicio se encomienda a sujetos especialmente cualificados» (López Guerra, 2018: 28). Para algunos autores, ésta es la única interpretación que permite dotar de contenido al derecho a recibir información veraz reconocido en el art. 20.1 d) de la Constitución ${ }^{19}$, aunque tampoco la opinión de la doctrina ha sido pacífica. El tenor literal del precepto parece orientado a un reconocimiento en igualdad de condiciones con el derecho a emitir información veraz: «Se reconocen y protegen los derechos: d) a comunicar o recibir libremente información veraz por cualquier medio de difusión». Sin embargo, en la práctica, la eficacia jurídica de uno y otro no es, en absoluto, comparable. Se acepta, por tanto, la distinción y autonomía de ambos derechos, ya que «las actividades de comunicar y recibir son radicalmente diferentes y revelan un conflicto de intereses, al menos, latente: quienes comunican quieren hacerlo sin trabas y quienes reciben lo comunicado pretenden, al menos, que no les engañen» (Escobar Roca, 2018: 98).

¿Tenemos derecho a que la información que recibamos sea veraz? Y, en su caso, ¿qué significado adquiere esa exigencia de veracidad del contenido? En uno de sus primeros pronunciamientos al respecto dijo el TC que el derecho a recibir «es una mera redundancia - no hay comunicación cuando el mensaje no tiene receptor posible- - , justificando su inclusión en el texto constitucional en «el propósito de ampliar al máximo el conjunto de legiti$\operatorname{mados}^{20}$ para impugnar cualquier perturbación de la libre comunicación social» (STC 6/1981, FJ 4).

A lo que más adelante añade, con ocasión de otro pronunciamiento, que «en el ejercicio de la libertad de información por parte del medio no sólo ha de salvaguardase la delimitación constitucional de este derecho sino también el derecho que corresponde a los lectores [...] a recibir una información veraz». Porque, si la diligencia profesional no fuera exigible, quedaría «afectado el derecho de los lectores a recibir una información veraz» (STC 336/1993, FJ 7).

nistraciones públicas en todos sus niveles», ofrece un balance del funcionamiento de las herramientas implementadas en los últimos años (Curto-Rodríguez, 2019: 180).

18 STEDH, de 8 de noviembre de 2016, caso Magyar Helsinki Bizottság c. Hungría, párrafo 166.

${ }^{19}$ Es un derecho inédito en los textos constitucionales de nuestro entorno, según el estudio realizado por Ripollés Serrano (2010) citado por Escobar Roca (2018: 97).

${ }^{20}$ Parece que abre la puerta a una cierta titularidad colectiva del derecho, a pesar de las dificultades para hacer efectivo su cumplimiento. 
Sin embargo, se trata de una doctrina que, si bien parece reconocer la existencia del derecho a recibir información veraz, entraña serias dificultades prácticas a la hora de delimitar su contenido y hacer efectivo su cumplimiento.

No parece que pueda traducirse en un derecho a recibir información — sea frente a los medios o frente a la administración - acerca de determinados hechos concretos. Esto supondría una interferencia en el establecimiento de la llamada agenda setting ${ }^{21}$ cuya configuración corresponde a los medios en exclusiva. Tampoco puede concretarse en la obligación de que la información de los medios sea accesible para todos los ciudadanos; estaríamos admitiendo una injerencia en la libertad de las empresas informativas para determinar el ámbito de difusión de sus contenidos e, incluso, para condicionar el acceso a una suscripción previa o al pago de cierta cantidad económica. Sirven estos argumentos para desechar la interpretación del derecho a recibir información veraz como un derecho de prestación, sin perjuicio de la posibilidad de esgrimirlo como defensa frente a ciertas intromisiones ilegítimas o actos concretos que impidan el acceso a la información que ya ha sido publicada. En cualquier caso, parece clara la intención del TC cuando afirma que:

[R]esultan menoscabados los derechos reconocidos en el art. 20.1 d) de la Constitución tanto si se impide comunicar o recibir una información veraz como si se difunde, se impone o se ampara la transmisión de noticias que no responden a la verdad, siempre que ello suponga cercenar el derecho de la colectividad a recibir, sin restricciones o deformaciones, aquéllas que sean veraces (STC 168/1986, FJ 2).

Los problemas aparecen a la hora de intentar garantizar la eficacia del derecho a recibir información entendido como derecho a la veracidad, esto es, como el derecho de todos los ciudadanos a que la información que recibamos sea veraz. Actualmente no podemos exigir su cumplimiento de forma individual $^{22}$; los detractores de esta posibilidad consideran que supondría imponer una obligación general de veracidad en la actividad periodística ${ }^{23}$,

${ }^{21}$ «Queda a criterio de los profesionales [...] decidir cuáles son las noticias de las que se va a informar y no se les puede obligar a informar de determinados hechos en contra de su criterio» (STS 114/2011, de 21 de febrero).

${ }^{22}$ Los titulares del derecho y, por tanto, legitimados para reclamarlo, serían todos los potenciales receptores de la información y esto explica, en buena medida, la resistencia generalizada a dotarlo de contenido.

${ }^{23}$ Cualquier información falsa podría ser objeto de reclamación por vulnerar el derecho a recibir información de los receptores potenciales del mensaje. En 1964, el Tribunal Supremo americano defendió la aplicación de un concepto flexible de veracidad, al considerar que la imposición de criterios rígidos puede conducir a un escenario de autocensura o desincentivo a la hora de publicar determinadas informaciones, lo cual va en detrimento de la propia democracia. New York Times c. Sullivan (376 U.S. 254 1964). 
con independencia de que el mensaje haya $-\mathrm{o}$ no- provocado algún daño a otros bienes jurídicos protegidos o derechos concretos: la mera falsedad de la información podría considerarse un daño al público. Sin embargo, no podemos olvidar que la veracidad es, en nuestra Constitución, condición para el ejercicio legítimo del derecho a la información ${ }^{24}$. No estamos descubriendo nada nuevo si afirmamos que la información protegida es la información veraz, sin que ello derive en un supuesto conflicto - que no es tal-, entre transmitir y recibir información, puesto que, si ésta no es veraz, queda fuera de la letra del artículo $20 \mathrm{CE}$ y, por tanto, no estará protegida. Esto no quiere decir que quede automáticamente prohibida - porque no lo está de forma expresa - pero, en caso de producir algún daño, aquellas informaciones que no son veraces carecen de protección constitucional. Tampoco debemos entenderlo como una prohibición general de información falsa o errónea - puesto que no es ese el sentido que damos a la veracidad - aunque no hayan provocado ningún daño, pero sí como fundamento para la exigencia de responsabilidad en los supuestos en los que, habiéndose desatendido el deber de diligencia y contraste de la información, pueda haberse vulnerado algún bien jurídico constitucionalmente protegido. Con esta idea clara, procede un ejercicio de concreción y delimitación del concepto que nos permita, efectivamente, garantizar su eficacia. Para ello, es necesario acudir a los diferentes instrumentos jurídicos aplicables, tanto en el ámbito internacional, como en nuestro ordenamiento.

\section{Eficacia del derecho a recibir información veraz en la búsqueda de la verdad}

En los tratados internacionales no se reconoce el de recibir información veraz como un derecho autónomo, aunque sí podemos extraer consecuencias jurídicas relevantes en materia de límites y de responsabilidad de la lectura de dos textos especialmente significativos. Así, el artículo 19.2 y 19.3 del Pacto Internacional de Derechos Civiles y Políticos establece que:

Toda persona tiene derecho a la libertad de expresión; este derecho comprende la libertad de buscar, recibir y difundir informaciones e ideas de toda indole, sin consideración de fronteras, ya sea oralmente, por escrito o en forma impresa o artística, o por cualquier otro procedimiento de su elección.

El ejercicio del derecho previsto en el párrafo 2 de este artículo entraña deberes y responsabilidades especiales. Por consiguiente, puede estar sujeto a ciertas restricciones que deberán, sin embargo, estar expresa-

${ }^{24}$ Para considerar, en caso de conflicto, que el derecho ha sido ejercido de forma legítima, es necesaria la concurrencia de los requisitos de veracidad y relevancia pública. 
mente fijadas por la ley y ser necesaria para: a) Asegurar el respeto a los derechos o a la reputación de los demás; b) La protección de la seguridad nacional, el orden público o la salud o la moral públicas. (Énfasis añadido).

En la misma línea, el art. 10.2 del Convenio Europeo de Derechos Humanos:

Toda persona tiene derecho a la libertad de expresión. Este derecho comprende la libertad de opinión y la libertad de recibir o de comunicar informaciones o ideas [...] El ejercicio de estas libertades, que entrañan deberes y responsabilidades, podrá ser sometido a ciertas formalidades, condiciones, restricciones o sanciones previstas por la ley, que constituyan medidas necesarias, en una sociedad democrática, para la seguridad nacional, la integridad territorial o la seguridad pública, la defensa del orden y la prevención del delito, la protección de la salud o de la moral, la protección de la reputación o de los derechos ajenos, para impedir la divulgación de informaciones confidenciales o para garantizar la autoridad y la imparcialidad del poder judicial. (Énfasis añadido).

Se reconocen, por tanto, deberes y responsabilidades aparejadas al derecho a recibir información veraz que bien podrían esgrimirse como principio o fundamento para la exigencia de ciertas reglas que garanticen la veracidad de la información (Espada, 2008), en la medida en que dichos deberes se encuentran estrechamente vinculadas a la finalidad que se atribuye a la inclusión del adjetivo «veraz» en el texto constitucional, que no puede ser otra que la de proteger a los ciudadanos, como receptores de información, en el proceso de construcción de la opinión pública. Y es que, a partir de la interpretación sistemática de la $\mathrm{CE}$, encontramos — al menos - tres bienes jurídicos en los que fundamentar la protección de este derecho: a) el principio democrático y de participación política (arts. 1.1 y $23 \mathrm{CE}$ ), en la medida en que la información sobre la gestión de lo público es presupuesto y garantía de legitimidad en el sistema representativo (Guichot et al., 2018: 29-32), permitiendo que el derecho a voto adquiera todo su sentido democrático. Si la información que recibimos es falsa o manipulada, el proceso de construcción de la opinión pública en el que se asienta la democracia se ve adulterado o desvirtuado ${ }^{25}$; b) la dignidad de la persona (art. 10.1 CE) — aunque el argumento pueda tacharse de paternalista - se ve afectada por la instrumentalización de los individuos, manipulados de forma intencionada con una finalidad concreta; c) el libre desarrollo de la personalidad (art. 10.1 CE), en la medida en que la recepción de información veraz también forma parte, como

${ }^{25}$ Seguimos aquí el sugerente concepto de Ingolfur «democracia simulativa», cuya obra recientemente ha sido traducida al castellano de la mano del profesor Eloy Garcia (Bluhdorn, 2020). Sobre el concepto, vale también la pena atender al prólogo del propio Eloy García a la obra del alemán, de título ya de por sí significativo: «Democracia y veracidad: La urgente necesidad de recuperar la veracidad en las instituciones democráticas». 
elemento determinante, de nuestro proceso de crecimiento personal y adquisición de las capacidades que resultan imprescindibles para desenvolvernos como adultos autónomos en sociedad.

Consecuencia de todo lo anterior, estaría justificada la interpretación del derecho a recibir información veraz reconocido en el art. 20.1 d) CE como derecho a la veracidad de los contenidos y las informaciones que se publican, materializado en forma de reglas y criterios de diligencia en torno a los cuales se construye en concepto jurídico de la veracidad, si bien es cierto que, para hacerlo efectivo, se hace necesario acometer una revisión de la categoría jurídica y de sus implicaciones, partiendo de la ya reiterada aclaración: no se pretende una imposición de la verdad ${ }^{26}$, ni la equiparación de ambos conceptos. Precisamente, es el hecho de que midamos la veracidad en términos de actitud o comportamiento profesional, el que permite establecer una correlación entre el derecho de los ciudadanos a la información y el deber profesional de informar adecuadamente, derivado de este mismo derecho (Azurmendi, 2005: 43). No en vano, la verdad o falsedad puede predicarse, en todo caso, de la información - de los acontecimientos narrados - mientras que la veracidad es un término que hace referencia a la actuación o modo de proceder del informador (Torres del Moral, 2010: 446).

Siguen oyéndose voces que defienden el requisito de la verdad en el acto comunicativo, como condición y «objetivo moral del periodismo» (Espada, 1996: 33), como una triple exigencia derivada de la Constitución, del público y de los cánones éticos; «la comunicación pública, o es verdadera o es otra cosa» (Sinova Garrido, 2015: 267 y 268). Frente a quienes entienden la verdad como elemento sustancial e irrenunciable en la comunicación ${ }^{27}$, una corriente más escéptica, construida sobre la base del principio de pluralismo, es la que entiende que un mismo hecho puede ser explicado de diversas formas (De Carreras Serra, 1996: 46-48) sin que ello implique necesariamente una merma de su sentido. La postura mayoritariamente aceptada ${ }^{28}$ es la que defiende la verdad como una búsqueda, un fin o un objetivo; como fundamento de la confianza frente a la habitual opacidad del Poder: «nadie quiere

${ }^{26}$ Como ya hemos indicado, el TC insiste en que «el concepto de veracidad no coincide con el de verdad de lo publicado o difundido. [...] Cuando la Constitución requiere que la información sea veraz no está privando de protección a las informaciones que puedan resultar erróneas, como estableciendo un deber de diligencia sobre el informador» (STC 29/2009, FJ 4). Sin embargo, la inclusión del término veraz, para algunos autores, aporta al contenido del derecho a la información una noción cercana a la verdad, en la medida en que «el adjetivo veraz se predica de aquello que tiene que ver con la verdad» (Azurmendi, 2005: 10).

27 Hasta el punto de que sin verdad desaparece la información misma.

${ }^{28}$ La Ilustración fue el momento histórico disruptivo que permitió dejar a un lado la verdad única e indiscutible (Villaverde Menéndez, 2002: 13 y ss.). 
que le engañen; necesitamos confiar en que los demás no nos mienten» (Williams, 2006 citado por Villaverde Menéndez, 2016: 195). La verdad informativa se nos antoja, por tanto, como una forma de actuar orientada al objetivo de no defraudar al receptor. Si se pretende $-\mathrm{y}$ así lo perseguimos de forma activa- que la narración de los hechos sea, al menos, verosímil, esto es, que resulte plausible, razonable y creíble, estaremos alimentando esa relación de confianza, en la base de la comunicación, a partir de la cual alcanzar consensos y aceptar la interpretación de la realidad desde el lugar común —aplicando el método tópico- (Viehweg, 2012). Es el consenso en Habermas, que bien merece la extensión de la cita:

[Necesario] para que el que habla y el que escucha puedan entenderse el uno al otro; el que habla debe tener la intención de comunicar un contenido proposicional verdadero, para que el que escucha pueda compartir su saber; el que habla debe querer exteriorizar las propias intenciones de modo verdadero, para que el que escucha pueda creer (tener confianza) en aquello que dice; el que habla debe finalmente buscar la expresión justa en la consideración de normas y valores vigentes, para que el que escucha la pueda aceptar de modo que ambos, el que habla y el que escucha, puedan ponerse de acuerdo en orden a un fundamento normativo reconocido. [...] El estar de acuerdo reposa sobre la base del reconocimiento de las respectivas pretensiones de validez: comprensibilidad, verdad, sinceridad y justicia en relación a normas y valores (Habermas, 1976: 176).

Es probable que sólo podamos hablar en términos jurídicos de verdad para referirnos a la verdad judicial: el uso del ius puniendi sólo es legítimo cuando se apoya en la verdad hallada sobre lo sucedido, presupuesto de validez de la decisión judicial que debe, ante todo, evitar el error $^{29}$. No se cuestiona la importancia que la verdad tiene para el derecho procesal - la práctica de la prueba - en la medida en que necesitamos determinar lo que se consideran hechos probados a partir de los cuales resolver el caso aplicando el derecho positivo vigente (Abellan, 2010; Conde, 1999; Taruffo, 2013). A pesar de esto, en el marco de los procesos judiciales — en el penal, especialmente - con frecuencia se plantea la pregunta de si puede existir una única decisión correcta para cada caso. Y, también en este ámbito, la respuesta tiene mucho que ver con la confianza que la aplicación del Derecho despierta en la sociedad, que viene dada por la existencia de reglas y procedimientos concretos legalmente establecidos para llegar a un resultado - decisión - que será verdadero - válido - en la medida en que se ha respetado dicho procedimiento reglado. No se trata, por tanto, de hallar la verdad en sentido objetivo o material, sino de respetar las normas que nos hemos

${ }^{29}$ El principio in dubio pro reo, así como el de presunción de inocencia persiguen, precisamente, evitar este error en la condena. 
dado como garantía de legitimidad y confianza en la toma de una decisión que tendrá como resultado lo que llamamos verdad judicia $b^{30}$.

Sin embargo, cuando la referencia a la verdad tiene que ver con lo que consideramos hechos históricos o verdad histórica, se acentúa la polarización en la disyuntiva que nos obliga a escoger entre la órbita del relativismo ${ }^{31}$ - desde esta perspectiva, verdad y mentira se consideran categorías totalitarias - y el convencimiento de la existencia de la verdad, como reflejo de la realidad, y la posibilidad de alcanzarla (Rubio Núñez, 2018: 226). El debate, a menudo planteado de la mano del derecho a la libertad de expresión, ha motivado interesantes reflexiones del TC acerca de la necesidad de proteger el debate sobre la historia:

Las afirmaciones, dudas y opiniones acerca de la actuación nazi con respecto a los judíos y a los campos de concentración, por reprobables o tergiversadas que sean $-\mathrm{y}$ ciertamente lo son al negar la evidencia de la historia - , quedan amparadas por el derecho a la libertad de expresión (art. $20.1 \mathrm{CE}$ ), en relación con el derecho a la libertad ideológica (art. $16 \mathrm{CE}$ ), pues, con independencia de la valoración que de las mismas se haga, lo que tampoco corresponde a este Tribunal, solo pueden entenderse como lo que son: opiniones subjetivas e interesadas sobre acontecimientos históricos (STC 214/1991, FJ 8).

Para el TC la verdad histórica pertenece a la esfera personal; podemos crearla, creerla y difundirla, en virtud de la libertad ideológica, la libertad de expresión y la de producción científica. Pero esto no puede servir de excusa para menospreciar y discriminar, porque «nuestro ordenamiento constitucional se sustenta en la más amplia garantía de los derechos fundamentales, que no pueden limitarse debido a que se utilicen con una finalidad anticonstitucional. Como se sabe, en nuestro sistema - a diferencia de otros de nuestro entorno- no tiene cabida un modelo de «democracia militante», esto es, un modelo en el que se imponga, no ya el respeto, sino la adhesión positiva al ordenamiento y, en primer lugar, a la Constitución» (STC 235/2007, FJ 4). La libertad de expresión no puede amparar las incitaciones al odio, los atentados contra la dignidad o la justificación del genocidio:

La especial peligrosidad de delitos tan odiosos y que ponen en riesgo la esencia misma de nuestra sociedad, como el genocidio, permite excepcionalmente que el legislador penal sin quebranto constitucional castigue la justificación pública de ese delito, siempre que tal justificación opere como incitación indirecta a su comisión (STC 235/2007, FJ 9).

${ }^{30}$ Esto sucede una vez que la sentencia es firme, produciéndose el efecto de cosa juzgada.

31 Según la cual todas las ideas serían igualmente válidas y, por tanto, verdaderas. 
En cualquier caso, cuando se trata de analizar la protección constitucional del debate histórico, como parte fundamental de la producción científica, el argumento es meridianamente claro:

[...] las valoraciones y juicios sobre los hechos históricos, y no solo sobre la actualidad o sobre el pasado más próximo, son tan inevitables como necesarios, sin perjuicio de la dificultad de que alcancen consenso o valoración unánime. [...] La posibilidad de que los contemporáneos formemos nuestra propia visión del mundo a partir de la valoración de experiencias ajenas depende de la existencia de una ciencia histórica libre y metodológicamente fundada (STC 43/2004, FJ 4).

A lo que añade que, la libertad científica, en lo que se refiere al debate histórico, «disfruta en nuestra Constitución de una protección acrecida respecto de la que opera para las libertades de expresión e información, [...] solo de esta manera se hace posible la investigación histórica, que es siempre, por definición, polémica y discutible, por erigirse alrededor de aseveraciones y juicios de valor sobre cuya verdad objetiva es imposible alcanzar plena certidumbre». Así,

La afirmación de la verdad absoluta, conceptualmente distinta de la veracidad como exigencia de la información, es la tentación permanente de quienes ansían la censura previa ... Nuestro juicio ha de ser en todo momento ajeno al acierto o desacierto en el planteamiento de los temas o a la mayor o menor exactitud de las soluciones propugnadas, desprovistas de cualquier posibilidad de certeza absoluta o de asentimiento unánime por su propia naturaleza. [...] Por todo ello, la investigación sobre hechos protagonizados en el pasado por personas fallecidas debe prevalecer, en su difusión pública, sobre el derecho al honor de tales personas cuando efectivamente se ajuste a los usos y métodos característicos de la ciencia historiográfica (STC 43/2004, de 23 de marzo, FJ 5). (Énfasis añadido).

El Tribunal Constitucional protege el análisis de la Historia, por encima de una determinada verdad histórica (Teruel Lozano, 2015: 51-59) —inalterable - que sólo desde el control y la imposición vertical podría garantizarse. También aquí, como en el mercado de las ideas ${ }^{32}$, se prefiere un debate libre, alejado de los marcos preestablecidos: las verdades. No quiere decir esto que se abrace la mentira en el discurso, pues para ello se sería necesaria la presencia del ingrediente subjetivo de la ecuación: la intención de mentir; de defraudar al receptor.

Descartado este punto, así como el de la verdad como imposición, resulta preferible esa noción de verdad interpretada en términos de búsqueda - camino-; pretensión de honestidad y validez de los contenidos. Cuando esto sucede, su significado coincide con sentido que damos al concepto

\footnotetext{
${ }^{32}$ En el marco de la tradición del liberalismo (Mill, 1984: 74-75).
} 
jurídico de veracidad en la información, alcanzándose así la — tantas veces rechazada - equiparación de ambos términos, que solo se hace posible a partir de una determinada actitud del creador del discurso.

Si el autor afronta el proceso narrativo con la pretensión de llegar a una verdad lógica o factual, esto es, siguiendo la clasificación de Arendt (1993: 248), aquella que se identifica con la transmisión de los hechos - aunque difícilmente pueda quedar circunscrita únicamente a estos- estará, al menos, afrontando la creación previa de los contenidos de acuerdo con la exigencia de veracidad - como una búsqueda honesta de la verdad- cumpliendo con este requisito para el ejercicio legítimo del derecho a emitir y recibir libremente información veraz. Es el único punto en el que verdad y veracidad pueden equipararse, dotando de pleno sentido al derecho a recibir información veraz. En cualquier caso, si se quiere que esta noción de veracidad llegue a ser algo más que un mero elemento retórico (Carrillo, 1988: 188), se hace necesario el compromiso - serio - de cumplimiento, por parte de los actores de la información, así como de los operadores jurídicos.

\section{LA VERACIDAD COMO LÍMITE AL EJERCICIO DE LA LIBERTAD DE INFORMACIÓN}

Según el diccionario de la lengua española, se predica el adjetivo veraz de aquello «que dice, usa o profesa siempre la verdad» ${ }^{33}$. Una definición - enmarcada en la corriente objetivista - que necesita del matiz recogido en el diccionario panhispánico del español jurídico: «la exigencia de veracidad de la información que requiere la jurisprudencia para amparar una determinada noticia no se identifica con la verdad material ni con una realidad incontrovertible, sino que solo obliga a que el informador haya realizado un previo contraste de lo que transmite como hechos con datos objetivos $\rangle^{34}$. Mientras la primera hace referencia a la dimensión objetiva de la veracidad - identificada con los hechos ${ }^{35}$ - , la segunda definición entronca con la dimensión subjetiva, vinculada exclusivamente a la actitud y modo de proceder del informador que debe creer en la adecuación de aquello que transmite ${ }^{36}$. Sin embargo, de aceptarse que la mera creencia del informador es suficiente, se

33 «Veraz», Diccionario de la Lengua de la Real Academia Española [En línea]: https://dle.rae.es/veraz [Consulta: 08/11/2020].

34 «Veracidad informativa», Diccionario panhispánico del español jurídico [En línea]: https://dpej.rae.es/lema/veracidad-informativa [Consulta: 15/11/2020].

${ }^{35}$ La información veraz sería aquella que coincide con los hechos acaecidos. En el Anteproyecto de nuestra Constitución, el artículo 20.1 d) hablaba de información "objetiva y veraz". Se suprimió finalmente el requisito de la objetividad alejándose de esta corriente.

${ }^{36}$ La información será veraz si éste cree que lo es. 
podría estar ocultando un «comportamiento negligente e irresponsable al transmitir como hechos verdaderos simples rumores carentes de toda constatación o meras invenciones o insinuaciones» (STC 144/1998, FJ 4).

Una postura intermedia es la que ha mantenido el Tribunal Constitucional y aceptado mayoritariamente la doctrina española ${ }^{37}$, considerando como veraz aquello que comporta una "adecuación aceptable entre el hecho y el mensaje» (Cremades García, 1994: 76). Así, una vez descartada la identificación de la veracidad con una verdad única y objetiva, se establece el requisito de la comprobación diligente de la información, como garantía del principio de pluralismo (Solozábal Echavarría, 1988). Veamos en qué términos.

\section{Veracidad $y$ diligencia profesional en la jurisprudencia del TC}

Ya sabemos que para el Tribunal Constitucional ${ }^{38}$ la «información veraz es aquella rectamente obtenida y difundida, aun cuando su total rectitud sea controvertible» (STC 6/1988, FJ 5; STC 121/2002). El motivo quedó recogido en la ya célebre cita - que no por reiterada pierde su importancia- con la que se introdujo un criterio interpretativo (Carrillo, 1988: 203) muy novedoso en aquel momento: «las afirmaciones erróneas son inevitables en un debate libre, de tal forma que, de imponerse la verdad como condición para el reconocimiento del derecho, la única garantía de la seguridad jurídica sería el silencio» (STC 6/1988, FJ 5). Así, se delimita - en el mismo fundamento jurídico - la información veraz de una forma flexible, acogiendo la protección constitucional - hoy totalmente aceptada - de los errores:

Cuando la Constitución requiere que la información sea «veraz» no está tanto privando de protección a las informaciones que puedan resultar erróneas -o sencillamente no probadas en juicio - cuanto estableciendo un específico deber de diligencia sobre el informador, a quien se le puede y debe exigir que lo que transmita como «hechos» haya sido objeto de previo contraste con datos objetivos.

Y añade, perfilando los límites del derecho, que quedará privado de protección:

[Q]uien, defraudando el derecho de todos a la información, actúe con menosprecio de la veracidad o falsedad de lo comunicado. El ordenamien-

${ }^{37}$ Pueden consultarse en este punto (Cremades García, 1994; Vega Ruiz, 1997; Villaverde Menéndez, 1995)

${ }^{38}$ La delimitación del concepto nos obliga a realizar un recorrido a través de los principales pronunciamientos del TC. Para ello, se ofrece una selección de los extractos que se consideran más relevantes, siguiendo un orden temático — descartando el cronológico- en la exposición. 
to no presta su tutela a tal conducta negligente, ni menos a la de quien comunique como hechos simples rumores o, peor aún, meras invenciones o insinuaciones insidiosas».

El fundamento de esta argumentación ha sido igualmente reconocido por el TEDH, para quien «la limitación del derecho a la información al relato puro, objetivo y aséptico de hechos no resulta constitucionalmente aceptable ni compatible con el pluralismo, la tolerancia y la mentalidad amplia, sin los cuales no hay «sociedad democrática» (STEDH, de 7 de diciembre de 1976, caso Handyside, párr. 65). Unos planteamientos, reiterados en numerosos pronunciamientos, en los que el TC pone el acento en el proceso de obtención de la información, descartando que el requisito de la veracidad pueda aplicarse como límite a la transmisión de opiniones y juicios valorativos, en la medida en que «la veracidad, entendida como diligencia en la averiguación de los hechos $[\ldots]$ no es exigible cuando lo que se ejercita es la libertad de expresión, pues las opiniones y juicios de valor no se prestan a una demostración de su exactitud, como sí ocurre con los hechos» (STC 216/2013). Es, por tanto, la información - su obtención y proceso de elaboración - la que queda sujeta a un deber de diligencia profesional del que pueden destacarse los siguientes elementos definitorios:

a) La diligencia profesional como rasgo de la elaboración de la información no puede analizarse en abstracto, ni «precisarse a priori y con carácter general, pues depende de las características concretas de la comunicación de que se trate por lo que su apreciación dependerá de las circunstancias del caso» (STC 53/2006, de 27 de febrero, FJ 6).

b) El estudio sobre la diligencia se centra fundamentalmente en el trabajo que el autor desarrolla en el momento anterior a la publicación; con carácter previo, tomando como referencia a los periodistas y profesiones de la información (Escobar Roca, 2006: 15):

El requisito de la veracidad deberá entenderse cumplido en aquellos casos en los que el informador haya realizado con carácter previo a la difusión de la noticia una labor de averiguación de los hechos sobre los que versa la información y la referida indagación la haya efectuado con la diligencia que es exigible a un profesional de la información (STC 53/2006, de 27 de febrero).

Lo relevante para la veracidad informativa "no es que a posteriori se pruebe en un proceso la realidad de los hechos, sino el grado de diligencia observado para su comprobación con anterioridad a la publicación de aquéllos (STC 68/2008, FJ 3; STC 129/2009, FJ 2).

c) En el análisis de la veracidad de la información, el deber de diligencia profesional admite grados de intensidad, en función de la relevancia del 
hecho narrado. Conforme aumenta la gravedad de las consecuencias derivadas del error en la información, mayor será en nivel de diligencia exigida:

El nivel de diligencia exigible al informador adquiere una especial intensidad cuando la noticia divulgada pueda suponer, por su propio contenido, un descrédito de la persona a la que la información se refiere (STC 139/2007).

Para precisar si en el presente amparo la información publicada resulta desprotegida por carencia de veracidad, es importante valorar la diligencia observada en la contrastación o verificación de lo informado, así como, en su caso, la repercusión de los errores en que se haya podido incurrir (STC 52/1996, FJ 6).

d) Adquiere especial relevancia el estudio sobre el uso que se hace de las fuentes, así como la labor de comprobación del periodista — si pudo o no tener acceso a la realidad de los acontecimientos acaecidos-. En este sentido, se tiene en cuenta, por un lado, la fiabilidad de las fuentes y, por otro, la tarea de contraste:

[E]stableciendo un específico deber de diligencia sobre el informador, a quien se le puede y debe exigir que lo que transmita como hechos haya sido objeto de previo contraste con datos objetivos (STC 52/1996, FJ 2).

- No se considera cumplido el requisito de la veracidad cuando la fuente es indeterminada $o$, en virtud del secreto profesional, dichas fuentes no son reveladas:

[E]l deber de diligencia en la comprobación razonable de la veracidad de la información no se satisface con la pura y genérica remisión a fuentes indeterminadas, que, en ningún caso, liberan al autor de la información del cumplimiento de dicho deber, [...] la obligación de contrastar la verosimilitud de la noticia es un deber propio y específico de cada informador, que es el que está ejerciendo el derecho a informar, y, por tanto, aquel al que incumbe no exceder sus límites, evitando la propagación de noticias que, aun procediendo de sedicentes fuentes bien informadas, no se ha preocupado de contrastar con diligencia razonable (STC 172/1990, FJ 3).

- La consideración de las fuentes como fiables o dignas de solvencia recae sobre aquellas que, en sí mismas, gozan de especial credibilidad, tales como instituciones oficiales o informes y documentos policiales:

La utilización como fuente directa para una información de unas diligencias policiales y judiciales abiertas en las que se confirma su contenido implica que los datos transmitidos en ese momento por el informante no puedan calificarse de producto de la mera invención o carentes de fundamento fáctico, quedando disipada de ese modo una eventual falta de diligencia en el contraste de la información difundida (STC 129/2009, FJ 2). 
- Así mismo, el Tribunal trata de averiguar si el periodista trató de ponerse en contacto con las personas aludidas para recabar su opinión al respecto:

[D]el carácter involuntario de dicho error es prueba el hecho de que el mencionado periodista también se preocupó de contrastar la información con la persona aludida en la misma, si bien este intento de ponerse en contacto con la persona afectada fue infructuoso al haberse ausentado ésta del municipio (STC 240/1992, FJ 7).

- En el caso de los escritos remitidos al periódico y publicados en la sección de cartas al director se exige la comprobación previa de la identidad de la persona que remite la carta. El responsable de ello es el Director de la publicación:

El deber de diligencia del Director del periódico entraña la comprobación de la identidad de la persona que figura como autor de la carta, antes de autorizar su publicación. Ello constituye, como es sabido, práctica habitual de los medios de comunicación, pues si esta diligencia no fuera exigible, obvio es, de una parte, que no quedarían debidamente deslindados, respectivamente, el ejercicio de la libertad de expresión de una determinada persona ajena al medio, que éste posibilita al publicar la carta, y el derecho que asiste al diario de informar de esa opinión a sus lectores; y de otro lado, ello también supondría que quedase afectado el derecho de los lectores a recibir una información veraz (STC 336/1993, FJ 7).

- Puede obviarse el análisis de la veracidad en aquellos casos en los que se cumple la teoría del reportaje neutral ${ }^{39}$, esto es, «aquellos casos en que un medio de comunicación se limita a dar cuenta de declaraciones o afirmaciones de terceros» (STC 232/1993, FJ 3):

En los supuestos de reportaje neutral, y esta es su más importante consecuencia, este Tribunal ha entendido que el deber de diligencia se cumple "con la constatación de la verdad del hecho de la declaración", pero no se extiende en principio a la constatación de la veracidad de lo declarado, pues tal responsabilidad sólo sería exigible por lo general al autor de la declaración (STC 232/1993, FJ 3).

e) El requisito de la veracidad no persigue la difusión de informaciones neutrales y objetivas:

[...] no siendo, por ello, exigible que las informaciones difundidas por los medios de comunicación social [...] sean neutrales o estrictamente objetivas, ya que lo contrario equivaldría a limitar el principio de pluralismo más allá de lo que consiente su condición de valor esencial de la socie-

${ }^{39}$ Por razones de espacio no me detengo en analizarlo en el presente trabajo. 
dad democrática, dejando reducida la libertad de información a inocua transmisión mecánica de hechos noticiables (STC 172/1990, FJ 3).

g) En sentido negativo, se establece:

- Que la intención del informador queda fuera del análisis de la veracidad:

No es canon de veracidad la intención de quien informa, sino su diligencia, de manera que la forma de narrar y enfocar la noticia no tiene que ver propiamente con el juicio de la veracidad de la información (STC 29/2009, FJ 4).

- Que «omitir datos esenciales en una información; silenciar puntos de vista; deformar la realidad con valoraciones intencionadas o destacando unos hechos sobre otros...» (Escobar Roca, 2018: 104), no se considera información veraz.

Estos son los criterios a partir de los cuales el Tribunal Constitucional ha configurado el requisito de la veracidad ${ }^{40}$, tal y como se ha venido aplicando hasta ahora, como límite al ejercicio de la libertad de información, sin olvidar que el análisis de su concurrencia se realiza siempre a la luz de las circunstancias de cada caso concreto. Si bien es cierto que la comprobación en virtud de tales parámetros puede resultar pertinente cuando el objeto en cuestión es una información creada en el marco de la actividad periodística profesional, ésta se torna impracticable cuando nos referimos a contenidos publicados por los nuevos actores del escenario comunicativo digital o cuando la transmisión de los mismos queda enmarcada en sectores de actividad de distinta naturaleza, como pueden ser la investigación científica o historiográfica. La naturaleza de relato - informativo, divulgativo o científico- determina la imposición de un mayor o menor grado de exigencia en la comprobación y contraste de las fuentes; algo que difícilmente podremos pedir - en los mismos términos - a un ciudadano de a pie, sujeto privado que, sin embargo, gestiona sus redes sociales con una clara vocación de proyección pública. Pero, las consecuencias que puedan derivar de sus mensajes - con una capacidad de difusión mayor, incluso, que un informativo líder de audiencia - deben poder someterse a un tamiz específico, acorde a los rasgos definitorios del contexto comunicativo vigente, pero tamiz de responsabilidad, al fin y al cabo.

Ante esta necesidad, se propone la superación del concepto clásico de veracidad para dar paso a un abanico integrado por distintos cánones de veracidad — en plural—, en función del sujeto que ejerce el derecho y del marco interpretativo o sector de actividad profesional.

${ }^{40}$ Es un concepto jurídico que toma como referente indiscutible al periodista tradicional que desarrolla su actividad bajo el paraguas de un medio de comunicación convencional. 


\title{
V. CONCLUSIÓN PROPOSITIVA: DEL CONCEPTO CLÁSICO A LOS CÁNONES DE VERACIDAD
}

\author{
«Los periódicos de aquí de la capital traen algo, \\ pero la verdad es mucho más hermosa».
}

Francisco Umbral, Madrid 1940.

Es innegable que vivimos, de la mano de las grandes plataformas y canales de comunicación digital, una transformación de los patrones clásicos. Se imponen nuevos hábitos de creación y consumo de la información, al tiempo que se consolida el caldo de cultivo perfecto para la desinformación. Algunas propuestas recientes ponen el foco en la responsabilidad de las plataformas ${ }^{41}$, convirtiendo a las redes sociales en una suerte de guardianes o garantes del contenido que se publica, como «agentes de seguridad interpuestos» (Serrano, 2019).

Esta es una - si no la principal — de las preocupaciones que se plantea en todos los debates y foros académicos que analizan el alcance de la esperada reforma digital en el entorno europeo, con la llegada de la Digital Service $A c t^{42}$. Lejos de esto y tomando distancia respecto de otras soluciones que pueden llegar a confundirse con el control público de los contenidos ${ }^{43}$, lo que aquí se plantea es una alternativa que busca, salvaguardando el principio de pluralismo, reformular el derecho para adaptarlo a las exigencias del nuevo contexto.

Como es sabido, la titularidad del derecho a la libertad de información corresponde los ciudadanos en su conjunto. Consecuencia de ello, su ejercicio no puede, por ejemplo, quedar sometido a una colegiación obligatoria que generaría distinciones entre los sujetos. «Esta argumentación que, en el

${ }^{41}$ A este respecto, Germán Teruel (2020) alerta de los riesgos asociados a la delegación de determinadas funciones en las corporaciones tecnológicas que pueden convertirse «en censores de la Red con potestades semi-públicas, algo que debe preocuparnos también desde la perspectiva de la garantía de la libertad de expresión y del pluralismo».

42 Veinte años después de la entrada en vigor de la Directiva 2000/31/CE sobre comercio electrónico, se encuentran en fase de tramitación dos propuestas legislativas llamadas a modificar el ecosistema jurídico de las plataformas y redes sociales: la Norma de Servicios Digitales (DSA) y la Norma de Mercados Digitales (DMA).

${ }^{43}$ El revuelo mediático generado por el «Procedimiento de actuación contra la desinformación» en el que se definen niveles de «prevención, detección, alerta, seguimiento y respuesta», así como los organismos - y sus funciones - que actuarán en cada caso. Entre ellos, destaca la comisión permanente contra la desinformación, coordinada por la Secretaría de Estado de Comunicación y presidida de forma ordinaria por el Director del Departamento de Seguridad Nacional. Véase «Orden PCM/1030/2020, de 30 de octubre, por la que se publica el Procedimiento de actuación contra la desinformación aprobado por el Consejo de Seguridad Nacional». Boletín Oficial del Estado (292), de 5 de noviembre de 2020. BOE-A-2020-13663. 
marco de los medios de comunicación mecánicos no era un problema, favorece la construcción de discursos vinculados a la democracia horizontal y se torna muy rígida», especialmente a la hora de abordar buena parte de los problemas descritos ${ }^{44}$ (De Miguel Bárcena, 2016: 151). Porque, a pesar de que cualquier ciudadano debería poder ejercer el derecho a la información, en la práctica, «es al periodista al que corresponde la búsqueda de información y su posterior transmisión» (STC 105/1983, FJ 11) quedando, el resto, excluidos de facto (López García y Boix Palop, 2005: 103). Partiendo de esta premisa y del papel destacado que el derecho a la libertad de información ocupa en nuestro ordenamiento, se han expuesto de forma ordenada cuáles son los criterios aplicables en los casos en que el informador es un periodista profesional. Sin embargo, éste ya no es el sujeto protagonista en el proceso de construcción de la opinión pública; han emergido nuevos actores - ciudadanos de a pie que publican con su teléfono móvil- y es preciso que nos acerquemos a nuevos formatos de responsabilidad.

En este sentido, sobre la base del derecho a recibir información veraz, interpretado como principio rector, podemos entender justificada la aplicación de ciertas reglas que garanticen con carácter general la veracidad de los contenidos que se publican, atendiendo a las circunstancias del caso concreto y a las condiciones del sujeto, con el objetivo de modernizar las técnicas tradicionales y de reformular los límites y criterios establecidos para el ejercicio de estos derechos, de modo que se adapten al nuevo contexto.

Sólo si aceptamos esa noción de la verdad - equiparable a la veracidad- que se nos presenta como un camino; una búsqueda honesta de sentido, podremos justificar el establecimiento de ciertas reglas o criterios de veracidad, que encuentran su fundamento en el derecho a recibir información veraz reconocido en el art. $20 \mathrm{CE}$. Unas reglas que necesariamente deben adaptarse al sujeto que ejerce el derecho, así como al marco interpretativo y al tipo de actividad que éste desarrolla. Al respecto, conviene distinguir una serie de cánones de veracidad delimitados, en primer lugar, en función de si los contenidos han sido difundidos en un contexto profesional o no profesional.

Esta primera categoría - la veracidad profesional- es la que aplicaríamos como límite al ejercicio de la libertad de información, en el caso de contenidos que hayan sido elaborados por un periodista o comunicador y publicados, ya sea a través de lo que entendemos como un medio institucionalizado de comunicación social, o a través de cualquier otra plataforma

${ }^{44}$ Cuestiones en su mayoría de carácter práctico, como la vulneración de otros derechos fundamentales, el incumplimiento de los límites materiales o el respeto a la propiedad intelectual. 
informativa, siempre que el emisor se dedique a ello profesionalmente. En definitiva, acudiríamos a este canon de veracidad cuando nos encontremos con informaciones elaboradas y publicadas por todos los que hacen de la actividad periodística su profesión.

Por su parte, el canon de veracidad no profesional sería el de aplicación a los conflictos en los que el sujeto que ejerce el derecho a la información es un ciudadano de a pie, sin vinculación con la actividad periodística o los medios de comunicación. Este canon deberá estar integrado necesariamente por criterios flexibles - rebajando la exigencia que el TC impone a los profesionales de la comunicación - pero sin desatender la responsabilidad de todo aquel que trasmite información, con el conjunto de la sociedad y con la democracia. Es la responsabilidad que se explica a partir de la dimensión objetiva de los derechos fundamentales que, en el caso que nos ocupa, justifica la especial protección que, en los sistemas occidentales, se confiere a los derechos a la comunicación, esenciales para la formación de la opinión pública libre.

Esta primera distinción, centrada en las cualidades del individuo que elabora el mensaje, resulta especialmente significativa teniendo en cuenta que, en el actual contexto, se añaden al esquema de los sujetos que intervienen en la comunicación, nuevos actores: las plataformas y canales digitales de transmisión - en el papel de la difusión de los contenidos-, los sujetos que actúan como emisores, puede hacerlo cualquier ciudadano; ya no es exclusivo de los profesionales de la comunicación, y, por último, los perfiles. El perfil de la red social puede coincidir o no con la identidad de la persona física que hay detrás. Y esto es determinante en la medida en que los bots no son titulares de derechos fundamentales. Solo las personas somos titulares del derecho a la libertad de información, sin embargo, existe un gran volumen de contenido que se genera y se difunde de forma automatizada a través de la red; contenido que no estaría protegido por la libertad de información.

Al mismo tiempo, podemos distinguir otros dos cánones de veracidad vinculados al ejercicio de otros derechos fundamentales. Se trata de cánones de exigencia diferenciados en la medida en que el discurso objeto de análisis puede ser resultado de una actividad distinta: la investigación científica o historiográfica. Incluso, podría resultar conveniente delimitar un último canon de veracidad - también al margen de la actividad periodística - configurado a partir de los criterios que se utilizan para determinar la llama verdad judicial; los hechos probados en el proceso penal. Sería una suerte de canon de veracidad judicial, aunque esto es algo que se aleja del objeto del presente trabajo, elaborado con una pretensión más modesta. En virtud de lo anterior, el esquema de los cánones de veracidad quedaría de la siguiente forma: 


\section{Veracidad como límite al ejercicio de la libertad de información}

A) Veracidad profesional: de aplicación a los contenidos elaborados y difundidos en el marco del ejercicio de la actividad periodística. Este canon de veracidad se configura a partir de los criterios que han sido desgranados por el Tribunal Constitucional en su jurisprudencia y expuestos en el epígrafe anterior. En todo caso, puede resultar conveniente ampliar el abanico de criterios con el objetivo de dar cabida a algunas de las reclamaciones que proceden de las asociaciones profesionales de periodistas y colegios profesionales ${ }^{45}$.

B) Veracidad no profesional: se trata de un canon de veracidad flexible, adaptado a las características que definen el nuevo contexto comunicativo en el que todos los ciudadanos participan en el debate público emitiendo mensajes que se difunden a través de las redes sociales. En este caso, sería conveniente incluir cuatro criterios o elementos a tener en cuenta:

a. La intención del emisor del mensaje. A pesar de que el TC ha descartado que este punto sea objeto de análisis cuando nos referimos a la veracidad de ámbito periodístico - se presupone que la finalidad del profesional es la de informar - puede ser determinante en el caso de un mensaje publicado por un ciudadano que, siendo de contenido falso, pueda causar algún daño. La diferencia entre un contenido erróneo y uno falso - lo que llamamos fake news - es, precisamente, la intención; el interés de engañar y manipular. De darse este elemento doloso, no podría entenderse cumplido el requisito de la veracidad de la información.

b. El ánimo de lucro. Puede ser relevante analizar si se trata de un portal o perfil falso, creado con la finalidad de obtener beneficio económico, multiplicado a partir de la difusión masiva de los mensajes, con cada clic.

c. La búsqueda del origen. En aquellos casos - bastante habituales - en los que se reenvía o reproduce determinado contenido de origen desconocido, sin la previa comprobación de su procedencia; puede tratarse de un mensaje creado fraudulentamente con intención de manipular y la mera transmisión estaría contribuyendo a multiplicar su efecto. En este sentido, sería conveniente conocer cuál fue la actitud del sujeto ante dicha situación, si se limitó a reenviarlo o trató de indagar en el origen del mensaje.

d. Gradación de la exigencia en los criterios de veracidad en función del efecto y capacidad de difusión de los contenidos. Los twits y mensajes cortos - propios del contexto de las redes sociales - bien pueden recibir el mismo tratamiento que la jurisprudencia da a los titulares de prensa ${ }^{46}$, condicionado «por su propia naturaleza, en la que destaca, de una parte, el hecho de su

${ }^{45}$ Esto queda pendiente para un ulterior trabajo.

${ }^{46}$ Registra muchos más lectores que el cuerpo de la noticia. 
necesaria concisión como presentación y resumen de la información y, de otra, el dato de su mayor difusión, pues es indudable que sus lectores son mucho más numerosos e impresionables que los del cuerpo de las noticias que presentan». De la aplicación analógica de esta misma argumentación, podemos extraer la conveniencia de aplicar los criterios del canon de veracidad, teniendo en cuenta la capacidad de alcance de los contenidos.

\section{Veracidad en el marco de otros derechos fundamentales}

A) Veracidad científica o historiográfica: se trata de un canon configurado sobre la base del derecho a la libertad ideológica (art. $16 \mathrm{CE}$ ) que admite, no sólo la investigación, sino también la interpretación de la historia, de forma que los relatos se construyen a partir de criterios más flexibles - como sostiene el TC - que los exigidos en el ámbito profesional de los derechos de la comunicación:

Si la historia solamente pudiera construirse con base en hechos incuestionables, se haría imposible la historiografía, concebida como ciencia social. En su ámbito, los historiadores valoran cuáles son las causas que explican los hechos históricos y proponen su interpretación, y aunque tales explicaciones e interpretaciones sean en ocasiones incompatibles con otras visiones, no corresponde a este Tribunal decidir, por acción u omisión, cuál o cuáles deban imponerse de entre las posibles. Son los propios ciudadanos quienes, a la luz del debate historiográfico y cultural, conforman su propia visión de lo acaecido, que puede variar en el futuro. (STC 43/2004, FJ 5).

Como dice el TC, «la veracidad de una narración de hechos nada tiene que ver con la "verdad histórica" y menos cuando lo que se examina, como bien dice el Tribunal Supremo, no es un hecho, sino la interpretación que del mismo se hace o la opinión que de él se tenga» (STC 43/2004, FJ 6). En cualquier caso, dejando margen suficiente a la interpretación y a la libertad ideológica, puede resultar conveniente incluir en este canon de veracidad otros criterios, presenten en todo proceso de producción científica, tales como:

a. La especificación del método. El respaldo de una metodología adecuada y sólida es determinante a la hora de considerar la veracidad de un trabajo de estas características, aunque su resultado pueda cuestionarse en términos de absoluta certeza o coincidencia con la realidad.

b. El adecuado estudio doctrinal y documental que sostenga, con el respaldo de fuentes bibliográficas suficientes, las hipótesis formuladas y los resultados de la investigación.

B) Veracidad judicial. Canon construido a partir de los criterios que sirven para determinar los hechos probados en el proceso penal a partir de los 
cuales dictar sentencia. No en vano, el ius puniendi se apoya en la verdad hallada sobre lo sucedido: «la averiguación de la verdad de los hechos es condición necesaria para la justicia de la decisión» (Taruffo, 2013: 13) que debe, en todo caso, evitar el error. En este sentido, el derecho a la presunción de inocencia (art. $24 \mathrm{CE}$ ) opera como regla probatoria del proceso, de forma que el inculpado queda absuelto si la culpabilidad ${ }^{47}$ no queda suficientemente demostrada (Montañés Pardo y Sánchez Tomás, 2018: 842). La búsqueda de la verdad judicial tiene, por tanto, la finalidad de verificar - validar - en virtud de determinados medios de prueba «pertinentes» ${ }^{48}$, que los hechos imputados efectivamente han sucedido, que son subsumibles en la norma penal que se aplica, así como la participación del acusado en los mismos. La naturaleza de este proceso justifica que los criterios de comprobación sean, en este ámbito, extremadamente rígidos, sujetos a reglas estrictas, legalmente establecidas, para llegar a un resultado adecuado.

Lo que aquí se plantea no es más que el germen de una propuesta que aún debe ser adecuadamente detallada y concretada. Requiere, sin duda, de un tratamiento profundo y exhaustivo — que está más allá de la pretensión de este trabajo- - a fin de delimitar sus contornos con la precisión suficiente para garantizar la seguridad jurídica de quienes puedan verse afectados. Se trata de una tarea que, por razones de espacio, no es posible abordar en estas páginas redactadas, en cualquier caso, con la idea de dar forma al boceto inicial de la alternativa: la aplicación de cánones de veracidad diferenciados, adaptados al sujeto y al ámbito profesional de la actividad que se desarrolla. Una propuesta orientada a la consolidación de los deberes y responsabilidades que se derivan del derecho a recibir información veraz, esgrimido como fundamento para la exigencia de la veracidad de la información, requisito para el ejercicio legítimo del derecho fundamental. No en vano, la información protegida es la información veraz.

\section{BIBLIOGRAFÍA}

Abellan, M. G. (2010). Los hechos en el Derecho. Bases argumentales de la prue$b a$. Madrid: Marcial Pons.

ARENDT, H. (1993). Entre el pasado y el futuro Ocho ejercicios sobre la reflexión politica. Barcelona: Península.

AzURMENDI, A. (2005). «De la verdad informativa a la "información veraz" de la Constitución Española de 1978. Una reflexión sobre la verdad exigible desde el derecho de la información». Comunicación y sociedad 18 (2), 67-83.

${ }^{47}$ La carga de la prueba corresponde, como es sabido, a la acusación.

48 Solo serán tenidas en cuenta aquellas pruebas que se practiquen en el juicio oral con plena observancia de los principios de publicidad, oralidad, inmediación y contradicción. La jurisprudencia prohíbe la valoración de pruebas obtenidas vulnerando los derechos fundamentales (STC 114/1984). 
Balkin, J. M. (2018). «Free Speech is a Triangle». Columbia Law Review (118), 2011-56. doi: https://ssrn.com/abstract=3186205.

BARnetT Lidsky, L. (2011). «Public Forum 2.0». Boston University Law Review 91 (155), 1975-2028.

Barrientos-Báez, A. Martínez-Sala, A. M. Altamirano, V. P. y Domínguez, D. C. (2021). «Fake news: The COVID-19 pandemic and its chronology in the tourism sector». Historia y Comunicacion Social 26, 135-148. doi: 10.5209/ HICS.74248.

Belardinelli, S. (1991). «La teoría consensual de la verdad de Jürgen Habermas». Anuario filosófico 24 (1), 115-124.

Bluhdorn, I. (2020). La democracia simulativa. Nueva política tras el giro posdemocrático. Bogotá, Colombia: Editorial TEMIS.

Boix Palop, A. (2016). «La construcción de los límites a la libertad de expresión en las redes sociales». Revista de Estudios Políticos (173), 55-112. doi: 10.18042/ cepc/rep.173.02.

(2020). «Los algoritmos son reglamentos: la necesidad de extender las garantías propias de las normas reglamentarias a los programas empleados por la administración para la adopción de decisiones». Revista de Derecho Público: Teoría y Método (1), 223-270. doi: 10.37417/RPD/vol.

Cantó, P. (2017). «¿Ya llegó Nico a tu WhatsApp? El dibujo salió de este instituto de Madrid». El País, marzo 2.

De Carreras Serra, L. (1996). Régimen Jurídico de la Información. Barcelona: Ariel Derecho.

CARrillo, M. (1988). «Derecho a la información y veracidad informativa». Revista española de derecho constitucional 8 (23), 187-206.

- (2013). «Internet como espacio público de la información». en Requejo Rodríguez, P. (coord), Derechos y espacio público. Cátedra de amparo de derechos y libertades (págs. 11-28). Universidad de Oviedo.

Casella, M. (2015). The social networks: an introduction. (Ebook).

Castells, M. (2006). La sociedad red: una visión global. Alianza Editorial.

Conde, F. M. (1999). «La búsqueda de la verdad en el proceso penal». Revista de derecho y proceso penal (1), 63-98.

Cotino Hueso, L. (2017). «Responsabilidad de intermediarios y prestadores de servicios de internet en Europa y Estados Unidos y su importancia para la libertad de expresión». Revista de Derecho, Comunicaciones y Nuevas Tecnologías (17), 1-32.

Cremades García, J. (1994). «La exigencia de veracidad como límite a las libertades informativas». en Estudios sobre derecho de la información (págs. 71-115). Madrid: Universidad Nacional de Educación a Distancia.

Curto-Rodríguez, R. (2019). «¿Qué información relacionada con la rendición de cuentas contienen los portales de datos abiertos autonómicos españoles?» Revista Española de Transparencia (9), 177-198.

Escobar RocA, G. (2006). «La idea de veracidad en la jurisprudencia del Tribunal Constitucional: exposición y crítica». Revista de responsabilidad civil, circulación y seguro (7), 4-16.

- (2018). «¿Tenemos realmente un derecho a recibir información veraz?» en Aznar, H., Pérez Gabaldón, M., Alonso, E., Edo, A. (dirs.), El Derecho de Acceso 
a los Medios de Comunicación. I. Legislación y Autorregulación (págs. 95-123). Valencia: Tirant Humanidades.

EsPADA, A. (1996). «Presente, verdad y objetividad (Notas sobre la relación entre periodismo y memoria)». Boletín de la Unidad de Estudios Biográficos, Universidad de Barcelona (1), 31-34.

- (2008). Periodismo práctico. Espasa.

Feldman, N. (2018). «If Trump Can't Block Twitter Users, Twitter Can't Either». Bloomberg, mayo 24.

Freelon, D. y Wells, C. (2020). «Disinformation as Political Communication». Political Communication 37 (2), 145-156. doi: 10.1080/10584609.2020.1723755.

Guichot, E. Boix Palop, A. Carrillo Donaire, J. A. De La Sierra, S. y Vázquez Alonso, V. J. (2018). Derecho de la comunicación. 5a Ed. Iustel.

Habermas, J. (1973). «Wahrheitstheorien». en Wirklichkeit und Reflexion. Walter Schulz zum 60. Geburtstag (págs. 211-266) editado por H. Fahrenbach y W. Schulz. Pfullingen.

(1976). «Was heisst Universalpragmatik?» en Sprachpragmatik und Philosophie (págs. 174-272) editado por K.-O. Apel. Frankfurt: Suhrkamp Verlag.

- (1981). Historia y crítica de la opinión pública. La transformación estructural de la vida pública. Barcelona: Gustavo Gili.

López García, G. y Boix PALOP, A. (2005). «Derecho y cuarto poder en la era digital». Revista de Estudios Políticos (130), 77-112.

López GuerRA, L. (2018). «El derecho a la verdad: ¿la emergencia de un nuevo derecho en la jurisprudencia del Tribunal Europeo de Derechos Humanos?» Anuario Iberoamericano de Justicia Constitucional (22), 11-30. doi: 10.18042/cepc/ aijc.22.01.

De Miguel BÁRcenA, J. (2016). «Las transformaciones del derecho de la información en el contexto del ciberperiodismo». Revista de Estudios Políticos (173), 141-168. doi: 10.18042/cepc/rep.173.04.

MiLl, J. S. (1984). Sobre la libertad. Madrid: Alianza Editorial.

MolinA, J. L. (1995). «Análisis de redes y cultura organizativa: una propuesta metodológica». Revista Española de Investigaciones Sociológicas (71-72), 249-63.

Montañés Pardo, M. Á. y SÁnchez Tomás, J. M. (2018). «La presunción de inocencia». en Rodríguez-Piñero y Bravo Ferrer, M., Casas Baamonde, M. E. (dirs.), Comentarios a la Constitución Española - Tomo I (págs. 840-859). Madrid: Boletín Oficial del Estado.

PAuner Chulvi, C. (2018). «Noticias falsas y libertad de expresión e información. El control de los contenidos informativos en la red». Teoría y Realidad Constitucional (41), 297-318. doi: 10.5944/trc.41.2018.22123.

Ripollés Serrano, R. (2010). Constituciones de los 27 Estados miembros de la Unión Europea. Congreso de los Diputados.

RodríGueZ-IzQuiERdo SERRANo, M. (2015). «El discurso de odio a través de Internet». en Miguel Revenga Sanchez (dir.), Libertad de expresión y discursos del odio (págs. 149-186). Universidad de Alcalá, Servicio de Publicaciones.

— (2019). «Las empresas tecnológicas en Internet como agentes de seguridad interpuestos». Revista española de derecho constitucional 117 (39), 77-100. doi: https://doi.org/10.18042/cepc/redc.117.03. 
Rubio NúÑEZ, R. (2018). «Los efectos de la posverdad en la democracia». UNED. Revista de Derecho Político (103), 191-228. doi: 10.5944/rdp.103.2018.23201.

Salaverría, R. Buslón, N. López-Pan, F. León, B. López-GoÑI, I. y Erviti, M.-C. (2020). «Desinformación en tiempos de pandemia: tipología de los bulos sobre la Covid-19». El Profesional de la Información 29 (3), 1-15. doi: 10.3145/epi.2020. may. 15.

Santos, F. R. (2008). Redes sociales y sociedad civil. Madrid: Centro de Investigaciones Sociológicas, Colección Monografías.

SERrA CRISTÓBAL, R. (2021). «De falsedades, mentiras y otras técnicas que faltan a la verdad para influir en la opinión pública». Teoría y Realidad Constitucional (47), 199-235.

SERrano, M. R. I. (2019). «Las empresas tecnológicas en Internet como agentes de seguridad interpuestos». Revista Espanola de Derecho Constitucional (117), 77 100. doi: 10.18042/cepc/redc.117.03.

SINOVA GARRIDO, J. (2015). «La objetividad y la verdad en el ejercicio del derecho a la información». en Derecho de la información: El ejercicio del derecho a la información y su jurisprudencia (págs. 267-289) editado por Ignacio BEL MALLÉN y Loreto CORREDOIRA Y ALFONSO. Madrid: Centro de Estudios Políticos y Constitucionales.

Solozábal Echavarría, J. J. (1988). «Aspectos constitucionales de la libertad de expresión y el derecho a a la información». Revista Española de Derecho Constitucional 8 (23), 139-155.

SuÁrez Villegas, J. C. (2015). «Aspectos éticos y deontológicos de la actividad periodística online. Su percepción por los profesionales». Revista Latina de Comunicación Social 1 (70), 91-109. doi: 10.4185/RLCS-2015-1036.

Suárez Villegas, J. C. y Cruz Álvarez, J. (2013). «Problemas éticos de la instantaneidad informativa en el entorno digital». Beatriz Lloves y Francisco Segado (coords.), I Congreso Internacional de Comunicación y Sociedad Digital.

TARUFFo, M. (2013). Verdad, prueba y motivación en la decisión sobre los hechos. México: Cuadernos de Divulgación de la Justicia Electoral.

Teruel Lozano, G. M. (2015). La lucha del derecho contra el negacionismo: una peligrosa frontera. Estudio constitucional de los límites penales a la libertad de expresión en un ordenamiento abierto y personalista. Madrid: Centro de Estudios Políticos y Constitucionales.

- (2016). «Libertad de expresión y censura en Internet». Estudios de Deusto 62 (2), 41. doi: 10.18543/ed-62(2)-2014pp41-72.

(2020). «Una lectura garantista de las nuevas tendencias en la lucha europea contra la difusión del mensajes terroristas en internet». Revista de Derecho Constitucional Europeo (34).

Torres del Moral, A. (2010). Principios de derecho constitucional español. Madrid: Servicio de Publicaciones. Universidad Complutense.

Urías Martínez, J. (2014). Principios de Derecho de la Información. $3^{\text {a }}$ Ed. Madrid: Tecnos.

- (2020). «La verdad no os hará libres (si es obligatoria)». Revista Contexto (260). VÁzquez Alonso, V. J. (2020a). «El problema constitucional de la falsedad». Agenda Pública | El País. 
(2020b). «Twitter no es un foro público pero el perfil de Trump sí lo es. Sobre la censura privada de y en las plataformas digitales en los EEUU». Estudios de Deusto 68 (1), 475-508. doi: 10.18543/ed-68(1)-2020pp475-508.

Vega RuIZ, J. A. de. (1997). Libertad de expresión, información veraz, juicios paralelos, medios de comunicación. Madrid: Centro de Estudios Ramón Areces.

Viehweg, T. (2012). Tópica y jurisprudencia. editado por T. de L. D. Picazo. Madrid: Civitas.

Villaverde MenÉndez, I. (1995). Los derechos del público. El derecho a recibir información del artículo 20.1 d) de la Constitución Española de 1978. Madrid: Tecnos.

- (2002). «Introducción histórica a las libertades de información y expresión». en Las libertades de información y de expresión: actas de las VII jornadas de la Asociación de Letrados del Tribunal Constitucional (págs. 11-44). Madrid: Centro de Estudios Políticos y Constitucionales.

(2016). «Verdad y Constitución. Una incipiente dogmática de las ficciones constitucionales». Revista Española de Derecho Constitucional 36 (106), 149201. doi: 10.18042/cepc/redc.106.04.

Vraga, E. K. y Bode, L. (2020). «Defining Misinformation and Understanding its Bounded Nature: Using Expertise and Evidence for Describing Misinformation». Political Communication 37 (1), 136-144. doi: 10.1080/10584609.2020.1716500. WiLliams, B. (2006). Verdad y veracidad una aproximación genealógica. Tusquets. 


\title{
DERECHO A LA VERDAD Y CÁNONES DE VERACIDAD
}

\author{
Right to the truth and canons of veracity
}

\author{
Ana Galdámez Morales \\ Contratada predoctoral FPU, Departamento de Derecho Constitucional \\ de la Universidad de Sevilla
}

http://dx.doi.org/10.18543/ed-69(2)-2021pp77-110

\section{Copyright}

Estudios de Deusto es una revista de acceso abierto, lo que significa que es de libre acceso en su integridad. Se permite su lectura, la búsqueda, descarga, distribución y reutilización legal en cualquier tipo de soporte sólo para fines no comerciales, sin la previa autorización del editor o el autor, siempre que la obra original sea debidamente citada y cualquier cambio en el original esté claramente indicado

Estudios de Deusto is an Open Access journal which means that it is free for full access, reading, search, download, distribution, and lawful reuse in any medium only for non-commercial purposes, without prior permission from the Publisher or the author; provided the original work is properly cited and any changes to the original are clearly indicated. 